\title{
No more moa
}

\section{Human activities depleted much of New Zealand's fauna. Let it be a warning.}

\author{
The Lost World of the Moa: \\ Prehistoric Life of New Zealand \\ by Trevor H. Worthy \& \\ Richard N. Holdaway \\ Indiana University Press: 2002. 718 pp. \\ \$89.95, $£ 57$
}

\section{Stuart Pimm}

Ninety years ago, Urupeni Puhara, a nonagenarian Maori chief, said that 'te kura' ('red bird'), not 'moa', was his ancestors' name for the country's great bird. 'Moa' means chicken, and its application, the chief thought, was a mistake by the Victorians who first found the giant bones. Neither he nor his grandfather had seen the bird, its eggs or its footprints. He heard stories that the bird had lived all over the North Island, but that it disappeared "after the coming of Tamatea", who set fire to the land.

This book elaborates on these stories, documenting in extraordinary detail what we now know about the fate of New Zealand's fauna and landscapes before and during the first human settlement some 700 years ago. Although there were regional changes in the distribution of New Zealand species at the end of the Pleistocene, there were no extinctions until after first contact. Then, armed with only limited Stone Age technologies (no bows or specialized spears, but certainly fire), Tamatea and his band of settlers extensively burned the forests and eliminated over 60 species of bird found nowhere else on Earth. We do not even know these birds' names.

Moa bones informed nineteenth-century debates, as they do modern ones. A missionary sent bones to England, where Richard Owen wrote about them in 1840. Extinction was then a relatively new idea, a denial of Scripture that required either a multiplicity of floods and creations or the hope of finding the species alive somewhere. Moa were so large that they would be hard to miss, and their demise was the subject of much debate. Some blamed climate change, and others felt that moa were in a kind of inexplicable but terminal decline before humans arrived.

This book's best chapter is its last, relatively short one. It summarizes the merits of these alternatives with 500 pages of detail in hand. The 'terminal decline' hypothesis falls to the mounting evidence that moa persisted until first contact, but it is also generally unscientific. The hypothesis states that the species that were lost were somehow flawed, but neither explains those flaws nor predicts which species will be next.

The 'climate change' hypothesis becomes increasingly implausible as more accurate methods date the extinctions. In the past 700 years, New Zealand's climate has changed little. Earlier changes were substantial, but caused no extinctions. The evidence that birds were slaughtered for food is so abundant that bones from some archaeological sites were hauled offby the wagonload for use in fertilizers. The most telling evidence is that only early settlements contain moa bones. Moa bones were "rare to nonexistent" in the diet of former moa hunters within the century after first settlement.

Hunting was not the only mechanism involved. Introduced rats probably eliminated many ground-nesting birds, including seabirds. Many seabird species became extinct after first contact, putting the onus on the climate-change hypothesis to explain marine as well are terrestrial changes. As Maori legends recount, and as radiocarbon dates confirm, fires changed the landscape rapidly and extensively. They probably destroyed half of the natural vegetation of the South Island. But Tamatea's band was only the first wave of human settlers. Following James Cook's mapping of the islands, contact with Europeans further changed the islands' habitats and diminished their diversity.

The consequences of both contacts were the loss of $41 \%$ of the islands' endemic bird species. Some 49 (51\%) of the North Island's bird species have gone, along with 53 (47\%) of the South Island's, and another 30 species are endangered, many of which survive only with active and expensive management. New Zealand's fauna only survived as well as it did because small offshore islands provided the last refuge for many species.

Hypotheses and statistics do not properly capture why this book is so compelling. It is not just about moa. Its core is an extensive description of kiwis and waterbirds, a huge eagle (one of the heaviest flying birds), the islands' many species of rail, its shorebirds, parrots and penguins, along with frogs, bats and reptiles. One of the bats belongs to an endemic family, and one of the reptiles, the tuatara, has distinct ancestors back in the Jurassic period. New Zealand is no upstart volcanic island colonized from afar. It broke off Gondwanaland 80 million years ago, carrying with it a unique and ancient flora and fauna. There was a unique coevolution too: the flora has an unusual number of divaricating plants, in which the branching shoots and twigs interlace. Life is different where the browsers are moa, not mammals.

Trevor Worthy and Richard Holdaway describe an isolated world that is an unfortunate model for present-day effects of human activities, where forest destruction is driving so many (overwhelmingly unnamed) species to extinction. Chief Puhara's oral tradition of fires, forest clearing and lost species contains deep and accurate insights into present-day human impacts. This book should prompt those who believe that 'things are getting better' to explain just how future massive global changes driven by sophisticated technologies and massive energy consumption will harm so few species, given that a few people with primitive technologies eliminated so many in New Zealand.

Stuart Pimm is at the Nicholas School of the

Environment and Earth Sciences, Duke University, Durham, North Carolina

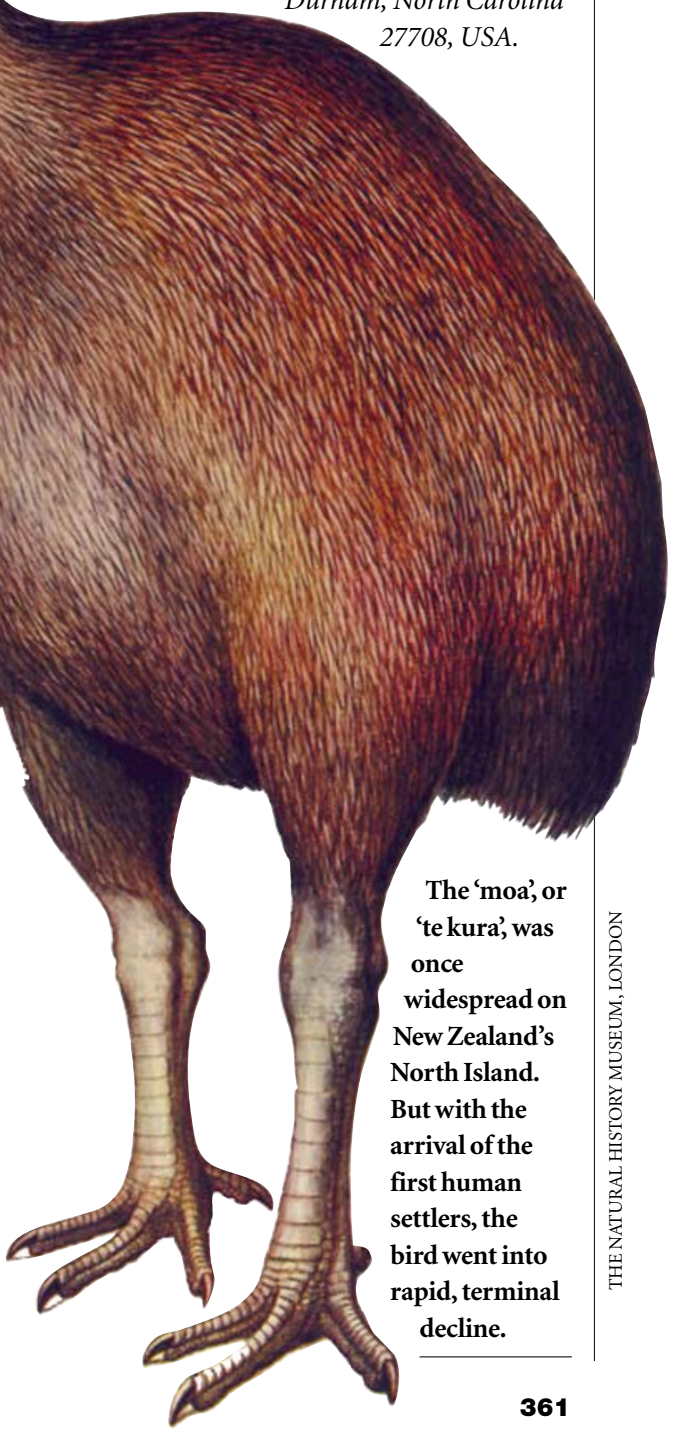

